\title{
Morphological, bathymetric and sedimentological surveys used to assess the coastline defensive measures
}

\author{
${ }^{1 * A}$ A Di Matteo; ${ }^{2}$ M. Milli \\ ${ }^{1}$ Via Gramsci, 76 - 66020 Paglieta (CH), Italy \\ ${ }^{2}$ Via Rimembranze, 10 - 61045 Pergola (PU), Italy \\ Received 29 February 2008; $\quad$ revised 18 March 2008; accepted 1 May 2008
}

\begin{abstract}
This paper outlines the results of a study recently carried out on the western coast of the Sestri Levante peninsula (Eastern Liguria - Italy), aiming to assess the effects of newly accomplished defensive measures against coastal erosion: the accretion of the beach with natural sand and its protection with artificial structures orthogonal and parallel to the shoreline. Through conventional and more innovative methodologies (respectively single beam echo sounders and global positioning system) the research work has resulted in a new evaluation of the morphological, bathymetric and sedimentological features that make up this shoreline and its volumetrical change over the century. The survey and the research carried out on the studied area have enabled us to give a more detailed picture of the evolution of the littoral, to assess the possible use of "non-traditional" techniques of beach development monitoring, to evaluate the volumetric variations of the emerged and submerged beaches, to establish the sedimentological activity of the beach after the latest nourishment measures, and finally, to verify the effectiveness of the protection measures implemented on this coastline. The acquired data have been stored in the Database and a Geographic information system has been used to process, analyze, and evaluate the results. The main findings show that the latest intervention has brought about a new phase in the evolution of the coastline, giving rise to a new pseudo-balanced condition. The re-distribution of materials used for the beach nourishment, leads us to believe that the defence underwater barrier has only partially worked. The main conclusion for a correct coastal zone management underline the necessity to plan local and more wide monitoring during at least 8-10 consecutive years.
\end{abstract}

Key words: Erosion, shoreline, global positioning system, single beam, artificial nourishment, geographic information system

\section{INTRODUCTION}

Coastal erosion is one of the most important socioeconomical problems that challenge the capabilities of states and local authorities. Whether it is due to natural or anthropogenic reasons, coastal erosion causes significant economical losses, social problems, and ecological damages (Corradi et al., 2000; özhan, 2002). The effects of coastal erosion differ across the world. All European coastal states are to some extent affected by coastal erosion. About twenty thousand kilometres of coasts, corresponding to $20 \%$, face serious impacts. The combined effect of coastal erosion, infrastructure development and the erection of defences to protect them have created, in many areas, a narrow coastal zone. Some examples: two thirds of the Belgian coast is

凶*Corresponding Author Email: geodma@tin.it

Tel.: +39 347 8489363; Fax: +39 0864726058 composed of sandy beaches and the remaining third is sealed by construction. As a result, one quarter of the Belgian coastline is eroding, which is a high rate in comparison to other countries. Italy also suffers from a high rate of erosion, $23 \%$, which is largely due to the rapid urbanisation of its coasts and beaches. On the other hand, the Finnish coastline is hardly affected because half of it is composed of hard rock, which erodes very slowly (European Commission, 2004). With a different approach to the subject, nowadays the commitment of research in this field is not simply to rebalance the conditions of an endangered coastline but also not to cause, or at least mitigate, nearby areas erosion, a problem already arisen in the past (Pranzini, 2004). In the Liguria region, the current state of the littoral environment is not better than all over Italy, 
maybe worse. The overall extent of the Ligurian coastline is $345 \mathrm{~km}$ : $189 \mathrm{Km}$ of rocky coasts, $41 \mathrm{Km}$ of beaches and $115 \mathrm{~km}$ of artificial coasts (Ferretti et al., 2003b). Previous studies conducted in the 1980s and 90 s showed a steady condition, whereas data collected in 2000 showed $80 \%$ of beach erosion (Fanucci et al., 1990 and 1987; Ferretti et al., 2003b). The first disruptive action of the meteo-marine dynamics can be traced back to the construction of a coastal railway line in the early XIX century, which directly caused the reduction of the beach surface and the building of defence strategies consisting of rocks placed close to the coast (Bensa et al., 1979; Ferretti et al., 2003c). Further disrupting elements include the aggregate extracted to hydrographic basin, the expansion of the tourist industry (Brandolini et al., 1992; Brandolini, 1995), which has given rise to the construction of ports and of greater habited areas closer to the coast, and the building of defence strategies targeting individual beaches.

\section{MATERIALS AND METHODS}

Study area and its historical evolution (1763-1996)

The studied area, called Baia delle Favole, is located on the eastern coastline of Liguria, North of the peninsula of Sestri Levante (Fig. 1).

The Baia delle Favole shoreline stretches for approximately $1.300 \mathrm{~m}$ and is divided in two parts by the mouth of the Gromolo river: the northern section stretches for approximately $800 \mathrm{~m}$; the southern one for $500 \mathrm{~m}$. In the central/southern section the shoreline stretches from NW to SE, while in the northern section from NE to SW. The central/southern section of the beach progressively extends from the mouth of the Gromolo river to the Sestri Levante peninsula, where the beach is wider than $100 \mathrm{~m}$. The southern section joins the headland of Sestri Levante, where, in the north, lies a breakwater of about $120 \mathrm{~m}$ that stretches from North to South. In the past, the small rocky island of Saint Nicolò lied in front of the town of Sestri Levante (the Latin Segesta Tigulliorum). As a consequence of the Gromolo river deposits, this island joined the land in the second half of the XVIII century (Cortemiglia, 1987). Between the second half of the XVIII century and the end of the XX century, the building of new touristic sea ports (Tomasicchio, 2001), such as Chiavari and Lavagna, caused an artificial extension of the mouth of the Entella river (Fig. 2).

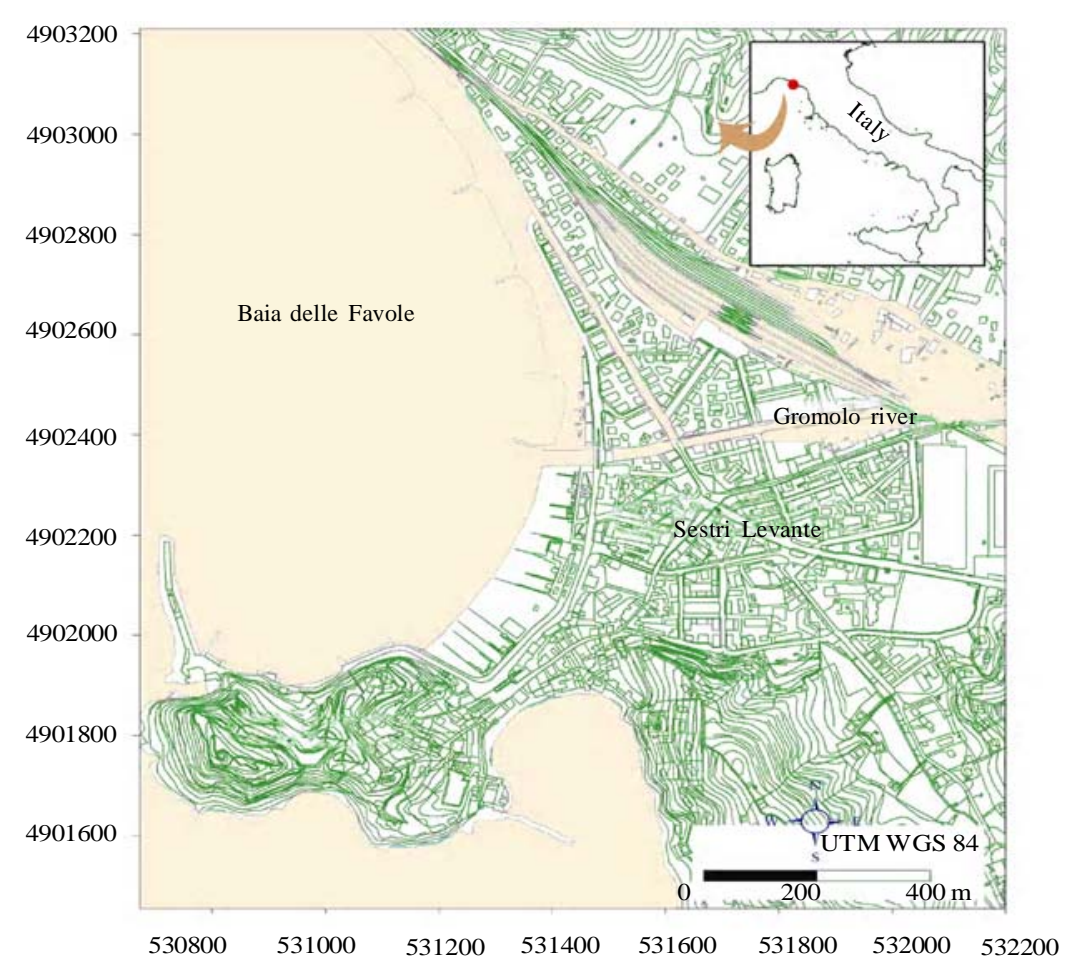

Fig. 1: The study area (Baia delle Favole) 


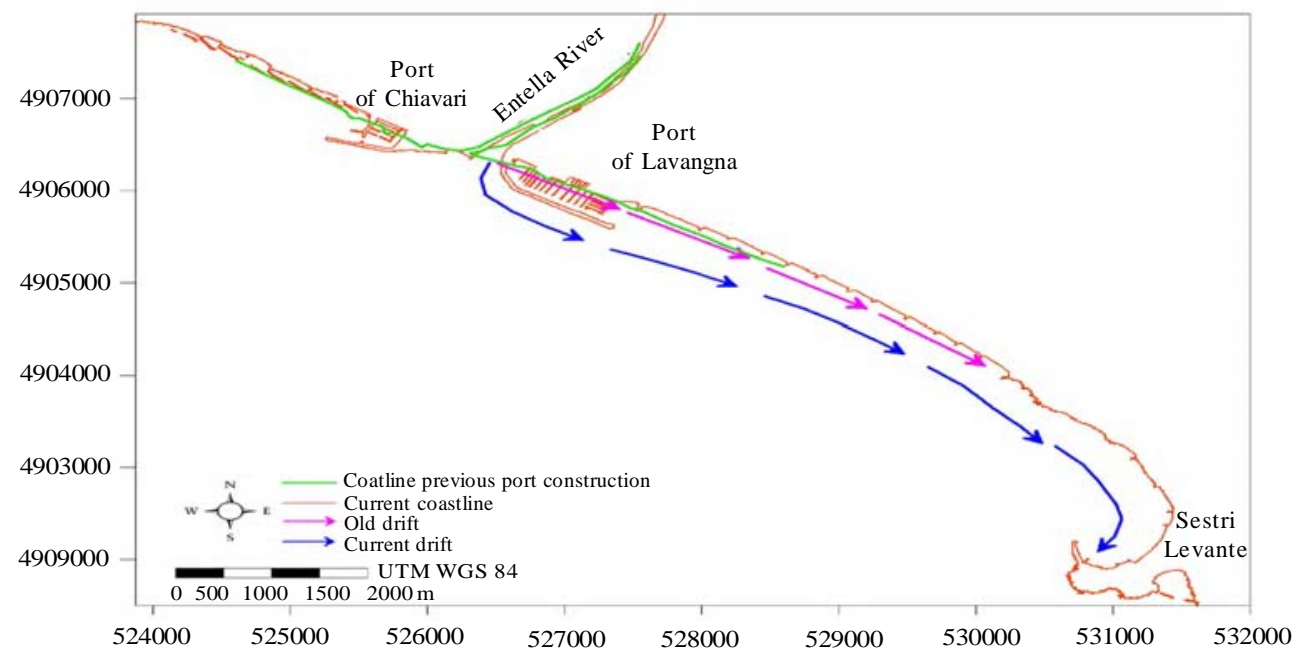

Fig. 2: Chiavari, Lavagna and Sestri Levante’s coastline

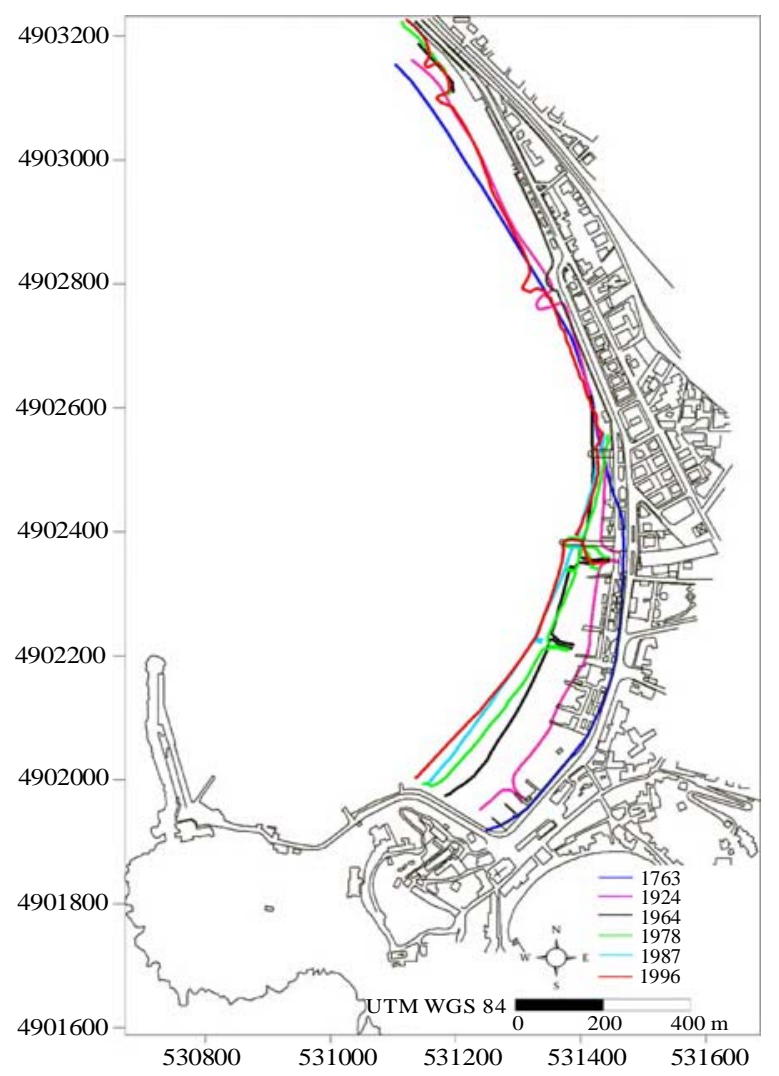

Fig. 3: The evolution of the shoreline

The new morphology of these coasts (Cortemiglia, 1978) produced a southerly drift of coastal materials (from the Baia delle Favole, in the north, to the southern area) and the partial backfilling of Sestri Levante Sea port (Cortemiglia, 1979 a). Starting from the early XX century, the marked erosion of these coasts in some cases affected the main transport routes (Cortemiglia, 1979 b; Terranova, 1979). This led, where necessary, to the building of new defensive measures close and parallel to the coast. These measures in turn caused an extensive and generalized destabilization, which even led to the erasure of entire stretches of beach. On the studied shoreline a number of measures are currently being implemented (Cortemiglia and Terranova, 1978; Aminti and Pranzini, 2000; Ferretti et al., 2003c, 2003d), including dismantling pre-existing measures and building a system of groynes, artificial barriers and artificial nourishment of the shoreline (over and under water). The shoreline's development obtained from the analysis of the data found in the bibliography (Cortemiglia, 1987; DEAM, 1997) is shown in Fig. 3.

The latest intervention on the studied area included the construction of 5 groynes, the artificial nourishment of beaches with $186.000 \mathrm{~m}^{3}$ of dry materials and the construction of a barrier about 5-6 m deep (Fig. 4). This project consisted of providing the shoreline with a complete system of groynes: each sector of shoreline was completed before moving to the next sector, from south to north, following an anti-longitudinal drift. The project aimed to re-establish a balanced situation in each sector in such a way as to absorb incident energy, to avoid reflection and to recreate a homogeneous coast. The works for this project started in November 1999 and ended in March 2002. 


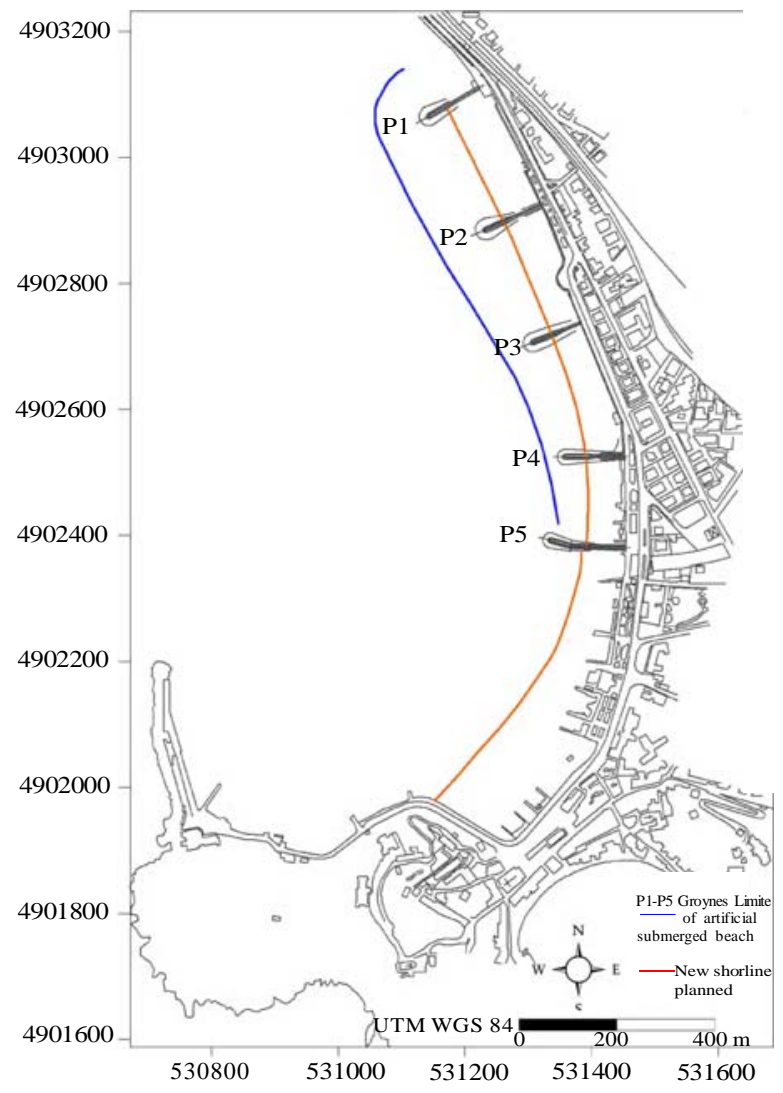

Fig. 4: The coastline management plan

\section{Methodology}

The methodology allowing a correct evaluation of the morphological variations of the emerged beach should take into account the following aspects:

- quick acquisition of data:

This is vital when working on fast-changing systems, such as beaches undergoing monitoring and implementation of defensive measures;

- accuracy of data:

Given that every small morphological variation leads to the displacement of large volumes of sediments, even a small evaluative mistake can lead to serious errors in the survey;

- rapidity in the elaboration of data:

This is vital in order quickly to obtain the necessary data and thus to plan subsequent surveys;

- readability of data:

The data must be gathered through valid and widespread methods which allow easy assessment and comparison of the final results.

The survey methodology for the area of study was global positioning system (GPS). This method satisfies

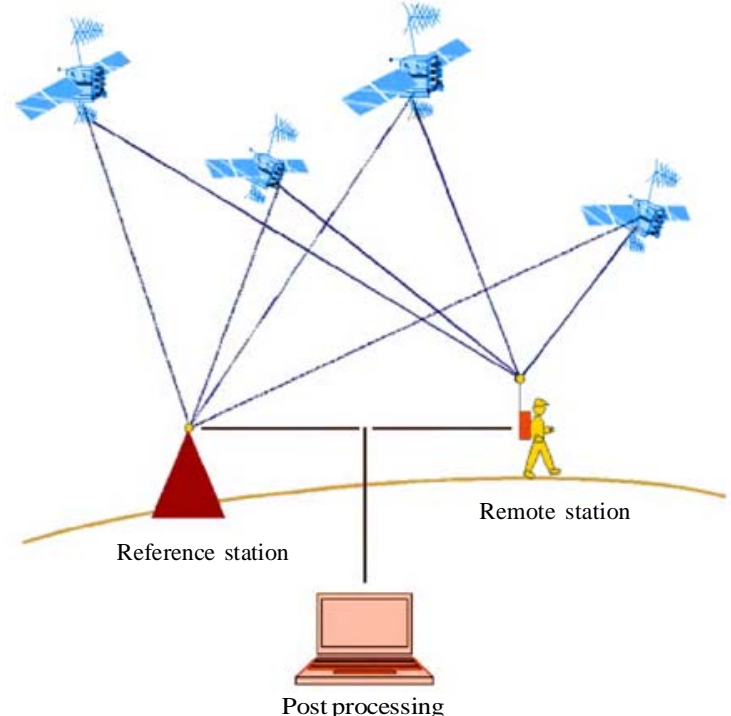

Fig. 5: The carrying out of surveys on the emerged beach

all the above parameters and confirms the increasing diffusion of GPS also in the study of shorelines and dynamic of littoral (Ciavola et al., 2000). In order to obtain accurate results, a couple of GPS receivers have been used - one with known coordinates, so that the relative position of the second one could be established. To avoid having to use two receivers, it is possible to replace the reference station with one of the many permanent GPS reference stations that are placed on the national territory, and to use this data as reference data (Cina, 2001; Secchia 2005). Thus the survey can be carried out using just one receiver, the Rover station, and the nearest permanent reference station as the Master station (Fig. 5).

In view of the above, it has been deemed appropriate to use the GPS permanent station of the School for Surveyors in Chiavari, for its position ensures a good spatial correlation between the two receivers and the elimination of most of the interference caused by atmospherics layers. The receivers were positioned in two different ways: statically and kinetically. The static receivers were positioned on fixed reference points, such as brick walls or other constructions; the kinetic receivers were used to carry out the actual morphological surveys on the beach. The GPS receiver used in the survey was the model Leica 500, which can provide the exact position in centimetres. The surveys were carried out in January and May 2004 and in May 2005 (Grassi, 2005 a, 2005 b). By using the Geographic 
Information System (GIS) it was possible to attain a Triangular Irregular Network (TIN) that reproduced the morphological development of this area and the defining features of the emerged beach (Fig. 6).

Morpho-bathymetric surveys were also carried out in the submerged beaches, in order better to assess the morphological changes that affected the Baia delle Favole following the implementation of preventive measures, and to analyse the subsequent formation of materials during the artificial nourishment phase. The most common system used for bathymetric surveys in small areas is currently the single-beam echo-sounder. The survey was carried out by boats that slowly run through fixed routes. Normally these routes are perpendicular to the shoreline in order better to measure the depth gradient. To check the accuracy of the data normally a number of oblique lines are also considered. In this case they used 13 sounding lines, perpendicular to the coastline and at a distance of 80-100 m and 2 control oblique lines, $350 \mathrm{~m}$ apart (Fig. 7). The elaboration of the data has led to the realization of a new bathymetric map, represented in Fig. 8.

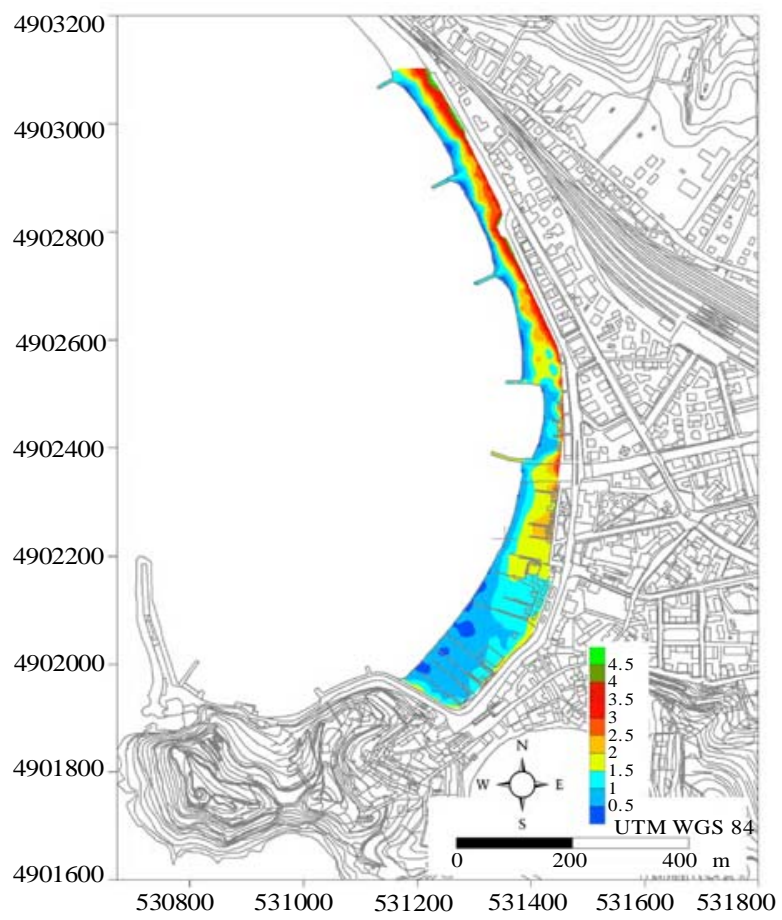

Fig. 6: Morphological features of the emerged beach (May 2005).

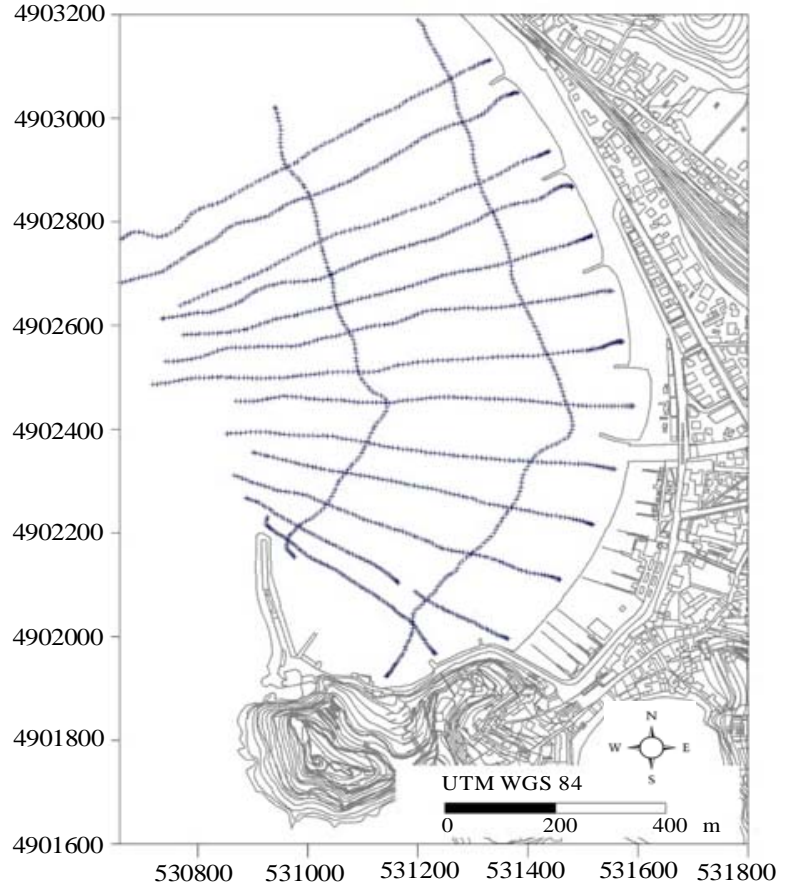

Fig. 7: Sounding lines

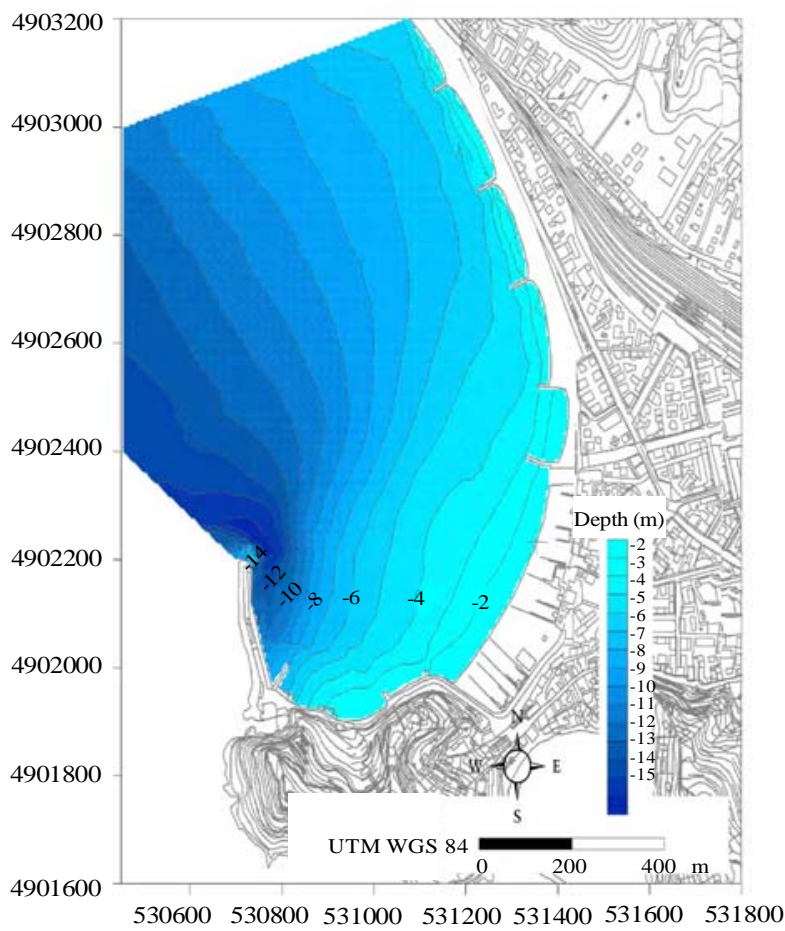

Fig. 8: Bathymetric survey in 2005 
The main factor in the artificial nourishment process is represented by the size of sediments used, for it is the size that mostly affects the duration of the process, the future use of the area and the width of the sandy shore (Dean, 2002). The samples for granulometric analysis have been taken from the points marked in Fig. 9.

On the emerged beach, samples of approximately 1 Kg were taken on the foreshore and on the berm, along the first 3-4 centimetres of sediments. Samples of submerged beach were taken using the bucket "Van Veen" along the bathymetric line, between $1 \mathrm{~m}$ and 14 $\mathrm{m}$ deep. This area is deemed to be the most sensitive to morpho-dynamic and sedimentological variations, due to the measures of the nourishment. Drawing on the results of the granulometrical analyses, the main statistical parameters were elaborated, namely mode, mean size grain, Inclusive Graphic Skewness, Inclusive Graphic Standard Deviation. These parameters were very useful to describe the present environmental conditions.

In the present survey the sedimentological values of the emerged beach resulted of less importance (and therefore have been omitted here). Their variation in fact is less connected to sedimentological processes than to the subdivision of the beach through a system of groynes.

With regards to the submerged beach, the most important parameters were elaborated and represented in thematic maps. The distribution map of mean size grain (Fig. 10) shows the presence of unrefined sand in the area submitted to the defensive and nourishing measures particularly in its low-coast side.

Due to the wave action these sediments loose their finest material which gathers next to the breakwater wharf. The distribution map of the mean size grain (Fig. 11) measured through surveys carried out in 2000 (Corradi, et al., 2003) that is before the re-nourishing process took place, shows the prevalence of fine sand. There is no more information on the area near the peninsula of Sestri.

The Inclusive Graphic Standard Deviation allows to assess graphically the sorting coefficient. This parameter, whose distribution is reproduced in Fig. 12, shows that both materials (of high and of middle quality) cover most of this area, except for the area near the first three groynes and the area east of the breakwater wharf.

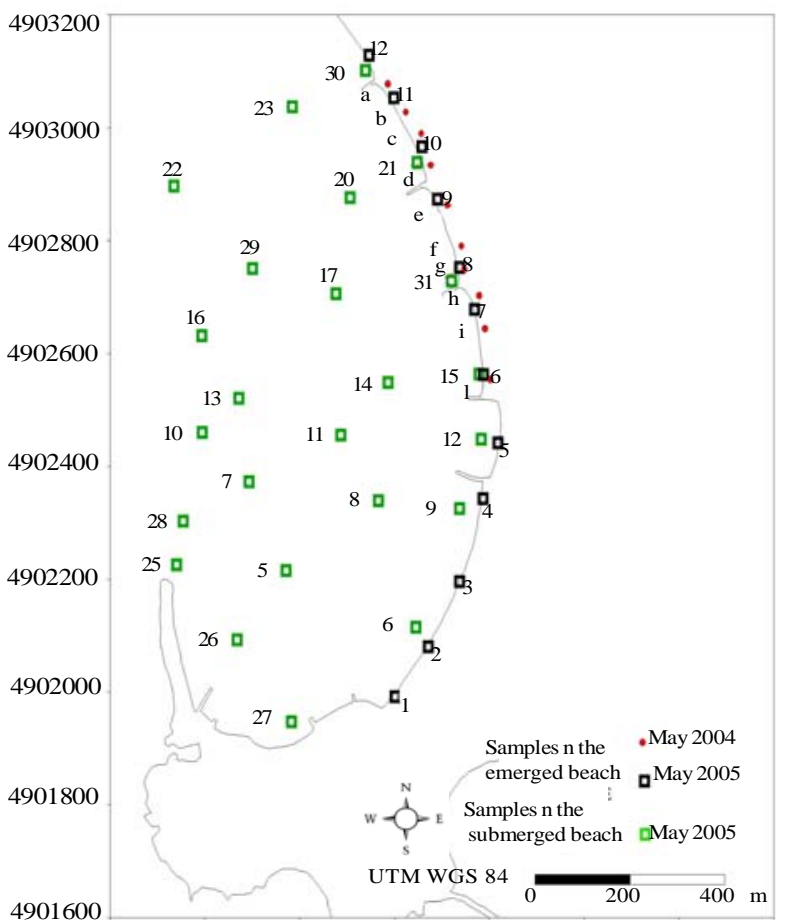

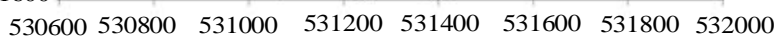

Fig. 9: Location of the analyzed samples on the emerged and submerged beach

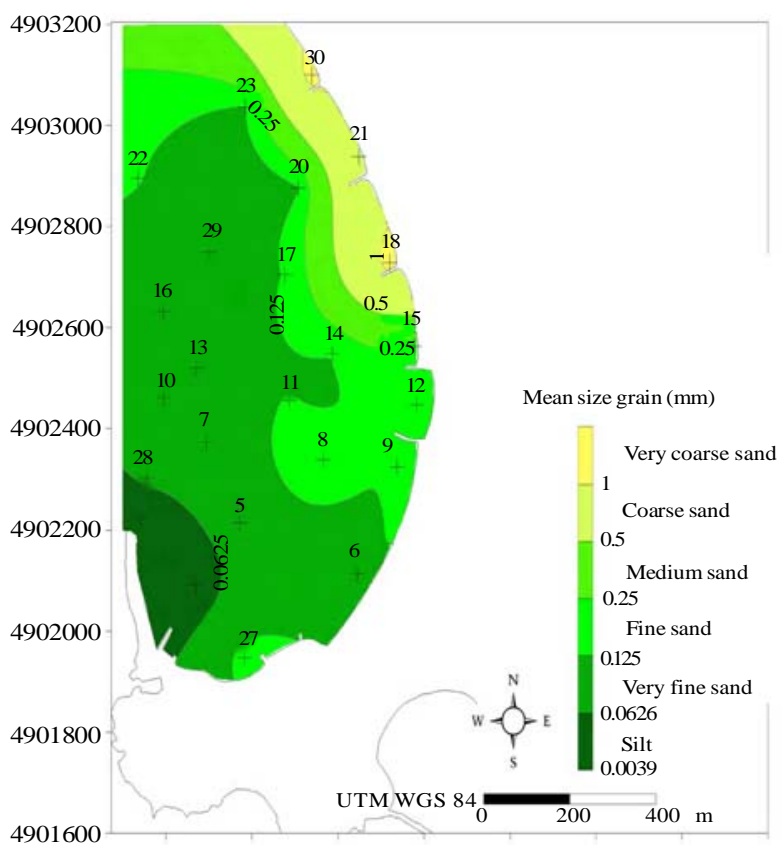

530800531000531200531400531600531800532000532200

Fig. 10: Distribution of mean size grain (in 2005) 


\section{RESULTSAND DISCUSSION}

At the end of this research project, and after elaborating and analysing the obtained data, it was possible to come to the following conclusions about the emerged beach, the submerged beach, and also about the efficacy of the intervention itself. The surveys allowed us to trace the development of the shoreline in comparison with the present bibliographic data (Fig. 13).

The volumetrical changes between the first and the second survey (carried out respectively in January and in May 2004) is minimal, as it was recorded a loss of materials of about $1700 \mathrm{~m}^{3}$, which, when considering the whole research area, corresponds to a variation in height of only to $0.06 \mathrm{~m}$. Between the first and the second survey - which were carried out with a 12 month gap (in May 2004 and in May 2005) - the data analysis shows a volumetric decrease of about $3000 \mathrm{~m}^{3}$ of materials. As consequence in this area it was recorded an altimetric change of about $0.10 \mathrm{~m}$. Moreover, it was deemed appropriate to estimate the volumetric variation affecting the emerged beach, which is often subject to sea erosion and thus is quite dynamic. This line of

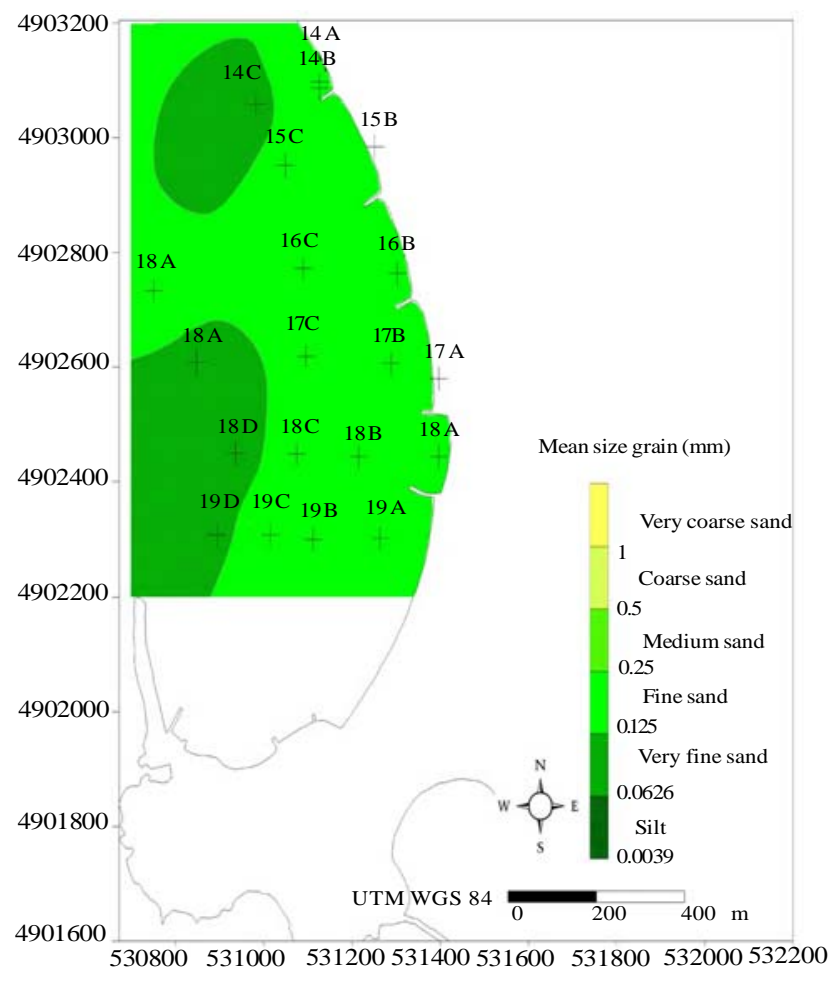

Fig. 11: Distribution of mean size grain (in 2000)

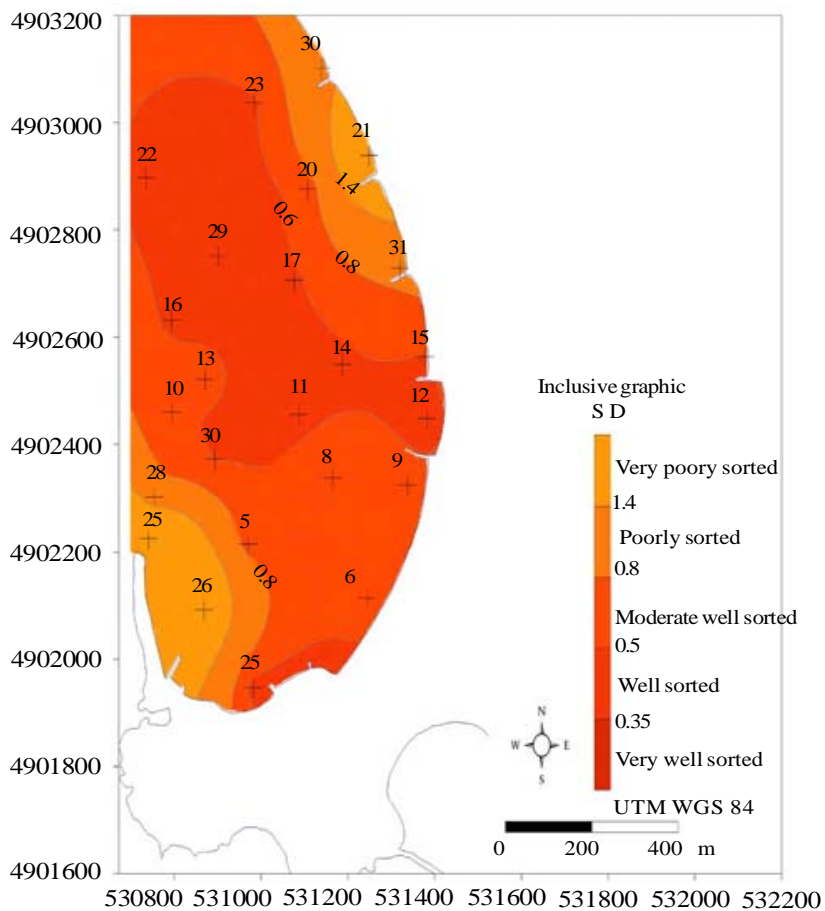

Fig. 12: Inclusive Graphic Standard Deviation (in 2005)

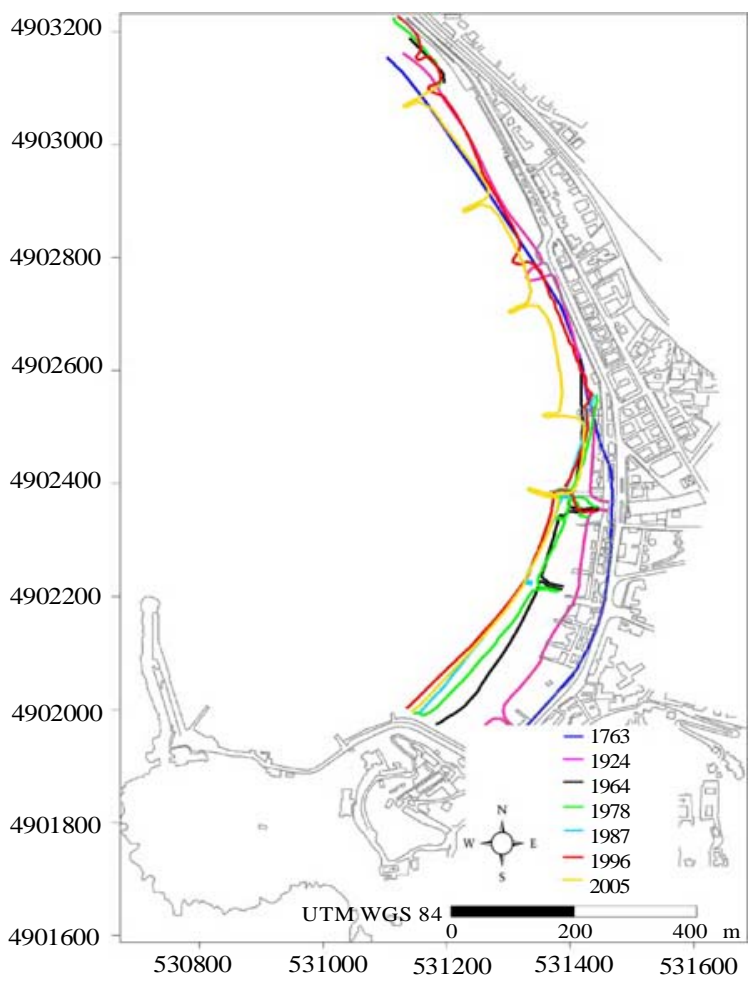

Fig. 13: Changes in the shoreline from 1763 to 2005 


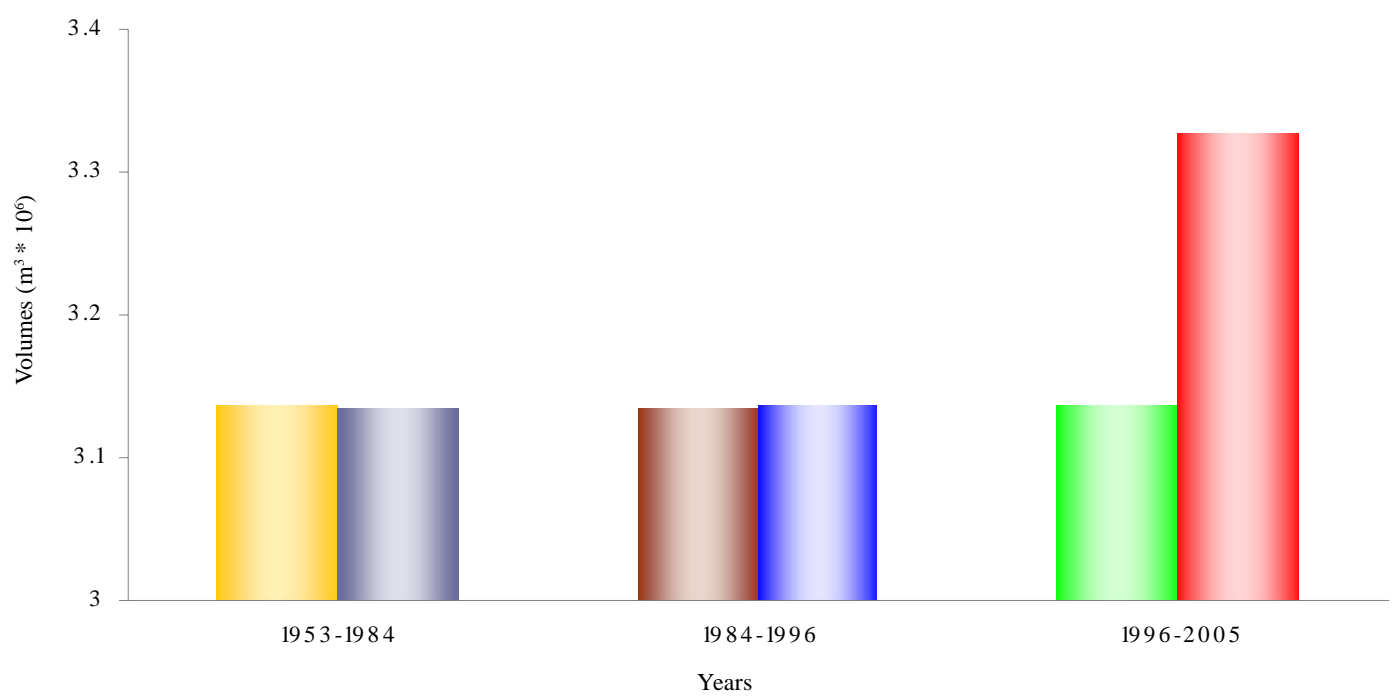

Fig. 14: Volumes of the submerged beach

emerged beach was located at 2,5 $\mathrm{m}$ above sea-level, between the foreshore and the storm berm.

In this area, the volumetric changes coincide and this result leads us to believe that:

- it is not correct to talk about loss of material between a survey and the next, but rather of a translation of volumes, which is due to the weather conditions in which the surveys take place;

- the emerged beach has reached its own balanced condition, but not the area near the groynes, which has not reached the planned equilibrium gradient of $3.3 \%$. This value was reached only in some areas covering $11.6 \%$ of the above area.

Today the northward coastline and the area near the groyne system present a low rate of retreatment, due its nature of pebbly and gravely shore, submitted to a drift to water-edge limited.

In order to give a more complete picture of the morpho-bathymetric evolution of the submerged beach, we considered some surveys carried out by public and private enterprises in 1953, 1984 and 1996. Using Geographic Information System (Ferrari et al., 2005) the old and the new data were compared: the volumetric

Table 1: Values of the volumetric changes of the submerged beach.

\begin{tabular}{lll}
\hline Years & Changes $\left(\mathrm{m}^{3}\right)$ & Changes in $\mathrm{m}^{3} /$ yearly \\
\hline $1953-1984$ & -1961 & -63 \\
$1984-1996$ & +2137 & +178 \\
$1996-2005$ & +190637 & +21182 \\
\hline
\end{tabular}

The values reported in Table 1 show the effects of the artificial nourishment process on this area: three years after the end of the works, the artificial materials used to nourish the beach have led to a new profile, whose gradient (for $92.9 \%$ of the area) equals $5 \%$. In the southern area, the entrainment of the flowing littoral seems to have stopped the continuous accumulation of thin materials both at the end of the bay - where the new shoreline has retreated compared to the previous survey carried out in 1996 (Fig. 13) and near the dam, where depth values have become higher than the 1996 data. These results lead us to believe that the intervention has brought about a new phase in the evolution of the coastline, giving rise to a new pseudobalanced condition (Dean, 1991). The presence of a groyne system in this area has allowed a partial slowdown in the longitudinal flowing of sediments, shifting the sedimentological flowing of the middle sand toward the centre of the bay. Before reaching the southermost part of the bay, sand is re-distributed westward, beyond the dam, thus reducing the formation of new land near the sea port.

Finally, the re-distribution of materials, used for the artificial nourishment, leads us to believe that the defence barrier has only partially worked, and that its effectiveness has decreased from north to south.

\section{CONCLUSION}

The work and research carried out on this area have enabled us: 
changes have been reported graphically in Fig. 14 and numerically in Table 1 below.

1. to give a more detailed picture of the evolution of the littoral;

2. to assess the possible use of "non-traditional" techniques to monitor beach development and to analyse theoretical and practical aspects of the above;

3. to assess, annually, the volumetric variations of the emerged beach;

4. to establish the sedimentological activity of the beach, as a result of last nourishment measures;

5. to assess the effectiveness of the measures implemented on this coastline.

With reference to the latest legislative changes that shifted authority over these matters from the State to the various Regions, this project can be seen as a first attempt to apply the evaluative parameters that were defined while planning defensive measures for the coastline and monitoring its results though a comparison with an intervention carried out before the new regional laws became effective.

\section{ACKNOWLEDGEMENTS}

Sincere gratitude is expressed to Dr. M. Ferrari and Prof. G. Fierro from University of Genova for their opinions and suggestions. Moreover, sincere thanks to Dr. Marina Spunta for her translation assistance throughout the article text. The authors have funded the research autonomously.

\section{REFERENCES}

Aminti, P. L; Pranzini, E., (2000). Indagine sperimentale per la ristrutturazione delle difese di Marina di Pisa., Studi Costieri, 12 (3), 57-70.

Bensa, F.; La Barbera, E; Taggiasco, F., (1979). Particolari aspetti evolutivi delle spiagge liguri., SAGEP edizioni., Available at Comune di Sestri Levante (Liguria-Italy)., 163.

Brandolini, P.; Repetto, A.; Rollando, A.; Terranova, R., (1992). Condizioni attuali delle spiagge da Sestri Levante a Levanto e loro stato di utilizzazione. In Atti del XXVI Congresso Geografia Italiana. Genova, Italy 4-9 May., 459-475.

Brandolini, P., (1995). Modificazioni della fascia costiera tra Portofino e Zoagli (Liguria Orientale) a seguito dello sviluppo turistico., Memorie Geografiche., 6 (1), 243-252.

Ciavola, P.; Gatti, M.; Tessari, U.; Zamariolo, A.; Del Grande, C., (2000). Caratterizzazione della morfologia di spiaggia lungo lo Scanno di Goro tramite tecniche GPS e rilievi batimetrici., Studi Costieri., 12 (2), 175-188.

Cina, A., (2001). GPS: principi, modalità e tecniche di posizionamento., Ed. Celid., ISBN 8876614176, 1-126.
Corradi, N.; Delbono, I.; Barsanti, M.; Morgigni, M.; Ferretti, O., (2003). Caratteri morfologici, sedimentologici ed evoluzione del litorale compreso fra Chiavari e Sestri Levante (Liguria orientale)., Studi per la creazione di strumenti di gestione costiera, Golfo del Tigullio., 21-39. Available on: http://www.santateresa.enea.it/wwwste/dincost/ dincost 2.html.

Corradi, N.; Fierro, G.; Ivaldi, R., (2000). The coastal erosion: a connection between natural processes and environmental planning. In Proceedings of International Meeting: Recent development of urban policies and communitarian experiences in urban requalification. Stockholm, Sweden 1012 September., 117-120.

Cortemiglia, G. C., (1979a). Caratteristiche correntometriche della surf zone di un tratto del litorale di Lavagna (Liguria Orientale). In Atti del Convegno Nazionale per la difesa del litorale di Chiavari, Lavagna e Sestri Levante dall'erosione marina. Cavi di Lavagna, Italy 18-19 May., 77-101.

Cortemiglia, G. C., (1979b). I fattori dinamici dell'erosione sulla spiaggia di Cavi di Lavagna (Liguria Orientale). In Atti del Convegno Nazionale per la difesa del litorale di Chiavari, Lavagna e Sestri Levante dall'erosione marina. Cavi di Lavagna, Italy 18-19 May., 103-116.

Cortemiglia, G. C., (1978). Le modificazioni dell'assetto strutturale del litorale di Lavagna quale fattore erosivo della spiaggia., Memorie Società Geologica Italiana., 2 (19), 369380 .

Cortemiglia, G. C., (1987). Evoluzione della Piana di Sestri Levante (Liguria Orientale) dal secolo XVII d.c. alla situazione attuale., Geografia Fisica e Dinamica del Quaternario., 10 (2), 122-131.

Cortemiglia, G. C.; Terranova, R., (1978). Realizzazione di una spiaggia artificiale a Lavagna (Liguria Orientale )., Memorie Società Geologica Italiana., 2 (19), 381-387.

DEAM., (1997). Studio meteo-marino e verifica del progetto di intervento lungo il litorale di Sestri Levante., http:// www.deamitalia.it.

Dean, R. G., (1991). Equilibrium beach profiles: characteristics and applications., Journal of Coastal Research., 7 (1), 5384.

Dean, R. G., (2002). Beach nourishment: theory and practice. World Scientific Publishing, ISBN 9810215487, 1-399.

European Commission., (2004). Living with Coastal Erosion in Europe. Sediment and Space for Sustainability. ISBN 92894-7496-3

Fanucci, F.; Firpo, M.; Ramella, A., (1987a). Genesi ed evoluzione di piane costiere del Mediterraneo: esempi di piccole piane della Liguria., Geografia Fisica e Dinamica Quaternaria., 10 (2), 193-203.

Fanucci, F.; Corradi, N.; Firpo, M.; Piccazzo, M.; Tucci S. (1990). Les côtes de la Mer Ligure: morphologie, dynamique et évolution., Littoral 1990., In Comptes rendus du 1er symposium international de l'Association européenne EUROCOAST. Marseille, France 9-13 Yuly., 82-86.

Ferrari, M.; Balduzzi, I.; Bozzano, A.; Artom C., (2005). The use of a GIS to evaluate the erosion of the ligurian littoral. In Proceedings of XXII International Cartographic Conference. A Coruna, Spain 9-16 July., ISBN: 0-958-460930 .

Ferretti, O.; Delbono, I.; Furia, S.; Barsanti, M., (2003). Elementi di gestione costiera., Tipi morfo - sedimentologici 
dei litorali italiani., ENEA RT/2003/42/CLIM., 4 (1), 1146.

Ferretti, O.; Delbono I.; Furia S.; Barsanti M., (2003a). Elementi di gestione costiera., Erosione costiera., Lo stato dei litorali italiani., ENEA RT/2003/43/CLIM., 4 (2), 1-167.

Ferretti O.; Delbono I.; Furia S.; Barsanti M.; Bozzano A., (2003b). Elementi di gestione costiera., Difese costiere rigide., Distribuzione e valutazione delle tipologie., ENEA RT/2003/44/CLIM., 4 (3), 1-140.

Ferretti O.; Delbono I.; Furia S.; Barsanti M., (2003c). Elementi di gestione costiera., Difese costiere morbide: ripascimenti artificiali., Rassegna tipologica., ENEA RT/2003/45/CLIM., 4 (4), 1-183.

Grassi, V., (2005). Tutorial sulla post elaborazione delle misure GPS., Geomedia., 5 (2), 38-45. ISSN 1970-9374.

Grassi, V., (2005). I programmi TGO e TTC di Trimble., Geomedia., 5 (3), 42-48. ISSN 1970-9374

özhan, E., (2002). Coastal erosion management in the Mediterranean: an overview., Available on: http://www.papthecoastcentre.org.
Pranzini, E., (2004). La forma delle coste. Geomorfologia costiera, impatto antropico e difesa dei litorali., Ed. Zanichelli., 1-256, ISBN 8808179605.

Secchia, M., (2005). Guida all'uso del GPS per il rilevamento del territorio e l'aggiornamento cartografico., Ed. Maggioli., 1-321. ISBN 97888387318397.

Terranova, R., (1979). Relazione tecnica sui litorali di Lavagna e di Sestri Levante. In Atti del Convegno Nazionale per la difesa del litorale di Chiavari, Lavagna e Sestri Levante dall'erosione marina. Cavi di Lavagna, Italy 18-19 May., 71-76.

Tomasicchio, U., (2001). Manuale di ingegneria portuale e costiera, Ed. BIOS, 1-720, ISBN 8877403179.

\section{AUTHOR (S) BIOSKETCHES}

Di Matteo, A., Degree in Geology, Freelance, Via Gramsci, 76 - 66020 Paglieta (CH), Italy.

Email:geodma@tin.it

Milli, M., Degree in Earth Sciences, Freelance, Via Rimembranze, 10 - 61045 Pergola (PU), Italy.

Email: manuelamilli@libero.it

This article should be referenced as follows:

Di Matteo, A.; Milli, M., (2008). Morphological, bathymetric and sedimentological surveys used to assess the coastline defensive measures. Int. J. Environ. Sci. Tech., 5 (3), 415-424. 